\title{
The Inverse Link between "Ideological-Absent" Albanian Voting Behavior
}

\section{Dorina Bërdufi}

\author{
"Aleksandër Moisiu" University, Albania; Email: berdufidorina@gmail.com
}

\section{Doi:10.5901/ajis.2015.v4n3s1p138}

\begin{abstract}
This paper presents a contribution toward understanding the complexity of Albanian electoral behavior. Long-term factors (behavior, value, family, age/gender group, etc.) and short-term factors (candidates, socio-economic-political situation, government actions, ect.) are analyzed. It is possible to try map an inverse linkage between the ideological and the absent voting behavior during the period 2007-2015. It was expected the "shrink" of the ideological voter and the slight increase of the absent voter ${ }^{1}$. Taking into consideration the not yet developed democracy, the empirical research data and analysis of election voting behavior of Albania outline this view.
\end{abstract}

Keywords: voting behavior, complexity, ideology-absent relationship

Two of the main forms of voting behavior are ideological and absent voting behavior. The first represents the voters who identify themselves with one party or the relationship with the party through psychological identification with the group. ${ }^{2}$ They have a psychological connection to their party. ${ }^{3}$ This is theoretically a stable indicator of the voting process; thus plays an important role in building policies, programs, group benefits, etc. On the other hand, the second type, represents the voters who feel removed or not attached to the political process. They simply don't feel part of it. Not feeling to be represented, they express it through the right not to participate in the decision making process; thus not being part of the system and being apart from it.

The actual electoral voting behavior in Albania, even after 25 years of democratization, remains still a non-stable and still reflects the dynamics of a continuous consolidating patterns. The grounds and drivers of the voting behavior relate to the social and economic status of the voters which eventually contributes to their vote positioning. As a unique case, different from the western countries, ideological voting during this period is interfered from actions of the moment. In the last years, due to the increase of the young voters (first time voter), there is a decrease of the ideological tendencies of voting behavior. Furthermore, there is a closeness of the ideological group towards the right and left wings, as in contemporary tradition. There is also a captured tendency of the absent voter, which are influenced by short time indicator factors. As electoral voting has not so much dependence from the social status, age, ect, absent voting does not actually depend directly from this long time factors (Dalton, R. J. (2000). The lack of internal party democracy and Albania political development has actually interfered in increasing the number of absent voter during this period, although not actually interfered at the same percentage rate to the ideological voter. It seems to be not such a direct relationship between ideological and absent voting behavior as it can be assumed

The "human" variable indicator (subjective) constitutes the ground stone in shaping the voting behavior. Notable in this case, unlike exact sciences, it is almost impossible to outline within a standard framework type an exact behavior attitude. Depending on internal and external factors, it results in major or minor changes in the "format" of the voter's behavior as per the respective country/state compared to others. Besides this argument, showing the inevitable dissimilarity among the composition of voting behavior types of various countries, the Albanian case adds another element to this variability/contrast being "its origin". Otherwise, it is noted as the lack of the former voting activities. This institution was built up from scratch staring in the end of late 1990 with the creation of the pluralistic system parties (previously there was only one party governing the state).

\footnotetext{
${ }^{1}$ Blerta Bitri, Diploma thesis "Voting Behavior in Tirana City. Udhëheqës shkencor Aleksandër Kocani, 2005

2 Paul Felix Lazarsfeld, Bernard Berelson, Hazel Gaudet, The People's Choice: How the Voter Makes Up His Mind in a Presidential Campaign, Columbia University Press, 1948

3 Stephen A. Jessee, Ideology and Spatial Voting in American Elections, Cambridge University Press: 2012
} 
This analysis is based also on empiric data retrieved from different surveys of the Albanian electorate ${ }^{4}$. The table and the respective graph presented below show the respondent responses when asked whether they are going to vote in the upcoming elections. The data shows an increase of the undecided voters in general with a different result only in 2007 during which it is noticed a decrease of undecided voters. This is related to the since the specific year corresponding to an election year in Albania. This means that the voters are undecided prior election year and do not have a clear line of logic in deciding on their vote. In terms of the election process, it can be derived that the voters' trend changes in terms of short term factors.

Table: Going to vote

\begin{tabular}{|c|c|c|c|}
\hline & Yes & No & Undecided \\
\hline 2005 & 31,4 & 49,9 & 19,1 \\
\hline 2007 & 45,6 & 22,2 & 7,5 \\
\hline 2008 & 50,2 & 29,9 & 18,8 \\
\hline 2012 & 41,1 & 33,1 & 25,7 \\
\hline
\end{tabular}

Furthermore, this result is supports the logic that economic situation may be a cause of voting behavior as also the democracy factors. This can be interpreted that this correlation can make the absent voter to become a pragmatist one, or to remain absent. On the other hand, it can be assumed that the ideological voters, of other factors as cultural or social groups (Inglehart, R., Wayne E. Baker, 2000), do not present very stable voting behavior; they might present tendencies to turn into a clientelistic voting behavior. The instability of the Albanian society in term of economy and democracy is the main factor contributing to such attributes.

As per presented data, Albanian electorate perceptions and feelings are in contradiction with their actions. This situation of non-stability, non-fluidity of real actions in relation to their perceptions could have some explanation alternatives: Vote manipulation (D. Bërdufi, MJSS, 2014), direct bribes for votes and/or changes of conditions through offers in the last period of pre elections, increasing considerably of the materialistic profile (which in itself affect the increasing of the voting behavior stability), ect.

The Albanian voter formation of values not from within (from the individual itself) but imposed from external factor has been inherited from the post-communist period. This factor has shaped both its internal and psychological identity. This confused situation for what it represents in essence, could be interpreted as an empty pot which is filled only from the outside (the government or political/economic leaders). This fact is confirmed also by the results of voting in communist period in which there were only two types of voting, pro or against the regime. There was an absence other impact factors such as candidates, political advertising, election campaigns, etc. Albanian voter unconsciously and passively is not committed to form a political identity or position in society, but still remains in his position at the end of the hierarchy leaving freedom to political group/parties to project the structure of their voter behavior identity. The vertical close relationship from individual to family interest and not the broader interest of the groups, brings lack of social clusters. Furthermore, it is important to note the impact of an unstable market economy, fragile democracy and not structured society psychology. Such as food, physical, economic protection, etc., are the primary needs to be met. These factors also theoretically govern individual towards materialistic, pragmatist, clientelist behavior.

The voter remains most of the time at the level of the party client dependent on individual interest, personal/family gains, employment, personal favors, short-term prosperity, etc. Translated in economic terms, it is a cost-benefit relationship for both parties. The voter sometimes chooses to vote ideologically (being loyal to a party) because of a benefit, protection of the workplace and/or raising the individual well-being, rather than against the formation of a substantial support on physiology bases. This factors, in the Albanian case, could be interpreted as some of the key factor in forming the ideological behavior.

Theoretically, this non action or non-thinking of change, can be interpreted as apathy, fatigue, lack of desire to change the political situation. Theoretically these indicators come as a result of the individual consciousness of the reality. This content is incomprehensible, abstract reality, being a relationship most of the time one way "up $=>$ down", while

${ }^{4}$ The empiric data is retrieved from surveys studies results, applied in the Political Science Department from my PhD supervisor Aleksandër Kocani. This data is taken also from these years analyses in bachelor student's diplomas at this department, leaded from my supervisor.

See: Kocani, A. Voting behavior studies. 2005-2012 
practically the desire for change and action is dependent from outside. In this situation they feel powerless to make a difference. It is a relationship inferred from "up", structured by the powerful groups political/economic and imposed "down". Several factors, such as not getting information from other sources, unwillingness, fear to make the change, etc., have created a strong interdependency relationship toward one-way direction.

Parties have no interest in changing this people legitimated format of voting, with little or no content of their policies. The other group (people) is interrelated by a solid form of clientelist relationship. The benefit it generates is only at the micro level, with no utility in wider society groups in general.

In this form, parties, especially large ones, maintain their stability in this relationship. Even if they make changes, these follow the direction of strengthening the not profitable for the country's democratic development content less relationship.

It is worth mentioning that the Albanian electorate voting behavior, in a large part of it, is not directly depended on their living conditions. They will not abstain on election day, even if the wellbeing indicator which directly affects the electorate is decreased. The non-satisfaction of public needs, lack of proper utilities supply, the high level of poverty, the high level of voting manipulation, ect. do not impact the voting trend as they should. Even with these negative factors, the electorate does not have the will to punish the government in power or the other parties, for not fulfilling them. This non rational voting behavior could be interpreted as an extreme ideology line, clientelism, not such a good voting behavior in contributing to the democracy development.

This results show that this group of voters have high chances of being manipulated from the interested political actors. Becoming so far even pragmatist voters, or absent ones, if they don't get the wanted offer from them.

\section{References}

Arrows, K. (1951). Social values and individual values. New York: John Willey \& Sons.

Bërdufi, D. Statistical Detection of Vote Count Fraud Albanian Parliamentary Election and Benford's Law), MJSC, Vol 5 No 2,January 2014

Budge, I., Crewe, I. \& Farlie, D. (1976). Party identification and beyond. New York: John Wiley.

Curtice, J. (2002). The state of electoral studies: mid-life crisis or new youth? Electoral Studies (21), 161-168.

Dalton, R. J. (2000). The decline of party identifications. In D. J. Russell \& M. P.

Inglehart, R., Wayne E. Baker, Modernization, Cultural Change, and the Persistence of Traditional Values, American Sociological Review, 2000,Vol.65 (February).

Inglehart, R., Modernization and Post modernization: Cultural, Economic and Political Change in 43 Societies. Princeton: Princeton University Press, 1997.

See: Kocani, A. Voting behavior studies. 2005-2012. See Also: Kocani, A., Researcher and supervisor of the bachelor Diplomas were the empiric data for the SWI are based. This data is taken also from these years' analyses in bachelor student's diplomas at this department, supervised/leaded also from my supervisor. I thank my supervisor for the data provided me in my PhD interest.

Stephen A. Jessee, Ideology and Spatial Voting in American Elections, Cambridge University Press: 2012

Paul Felix Lazarsfeld, Bernard Berelson, Hazel Gaudet, The People's Choice: How the Voter Makes Up His Mind in a Presidential Campaign, Columbia University Press, 1948 